\title{
Structure of Hierridin C, Synthesis of Hierridins B and C, and Evidence for Prevalent Alkylresorcinol Biosynthesis in Picocyanobacteria
}

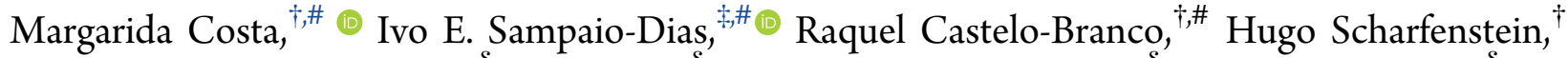 \\ Roberta Rezende de Castro, ${ }^{\S}$ Artur Silva, ${ }^{\S}$ Maria Paula C. Schneider, ${ }^{\S}$ Maria João Araújo, ${ }^{\S}$ \\ Rosário Martins, ${ }^{\dagger, \perp}$ Valentina F. Domingues, ${ }^{\| \odot}$ Fátima Nogueira, ${ }^{\nabla}$ Vera Camões, \\ Vitor M. Vasconcelos, ${ }^{\dagger, O}$ and Pedro N. Leão $*^{\dagger \dagger}$
}

\footnotetext{
${ }^{\dagger}$ Interdisciplinary Centre of Marine and Environmental Research (CIIMAR/CIMAR), University of Porto, Avenida General Norton de Matos, s/n, 4450-208 Matosinhos, Portugal

${ }^{\ddagger}$ LAQV-REQUIMTE, Department of Chemistry and Biochemistry, Faculty of Sciences, University of Porto, Rua do Campo Alegre 687, 4169-007 Porto, Portugal

${ }^{\S}$ Institute of Biological Sciences, Center of Genomic and System Biology, Federal University of Pará (UFPA), Belem, PA66075-110, Brazil

${ }^{\perp}$ Health and Environment Research Centre (CISA), School of Health, Polytechnic Institute of Porto, Rua Dr. António Bernardino de Almeida, 400, 4200-072, Porto, Portugal

"REQUIMTE/LAQV, Instituto Superior de Engenharia, Instituto Politécnico do Porto, Rua Dr. António Bernardino de Almeida, 431, 4200-072 Porto, Portugal

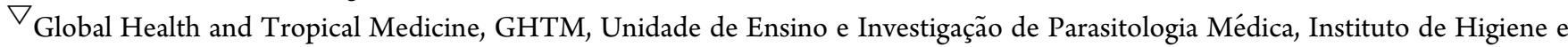
Medicina Tropical, IHMT, Universidade Nova de Lisboa, UNL, Rua da Junqueira no. 100, 1349-008 Lisboa, Portugal

ODepartment of Biology, Sciences Faculty, University of Porto, Rua do Campo Alegre, 4169-007 Porto, Portugal
}

\begin{abstract}
Small, single-celled planktonic cyanobacteria are ubiquitous in the world's oceans yet tend not to be perceived as secondary metabolite-rich organisms. Here we report the isolation and structure elucidation of hierridin $\mathrm{C}$, a minor metabolite obtained from the cultured picocyanobacterium Cyanobium sp. LEGE 06113. We describe a simple, straightforward synthetic route to the scarcely produced hierridins that relies on a key regioselective halogenation step. In addition, we show that these compounds originate from a type III PKS pathway and that similar biosynthetic gene clusters are found in a variety of bacterial genomes, most notably those of the globally distributed picocyanobacteria genera Prochlorococcus, Cyanobium and Synechococcus.
\end{abstract}

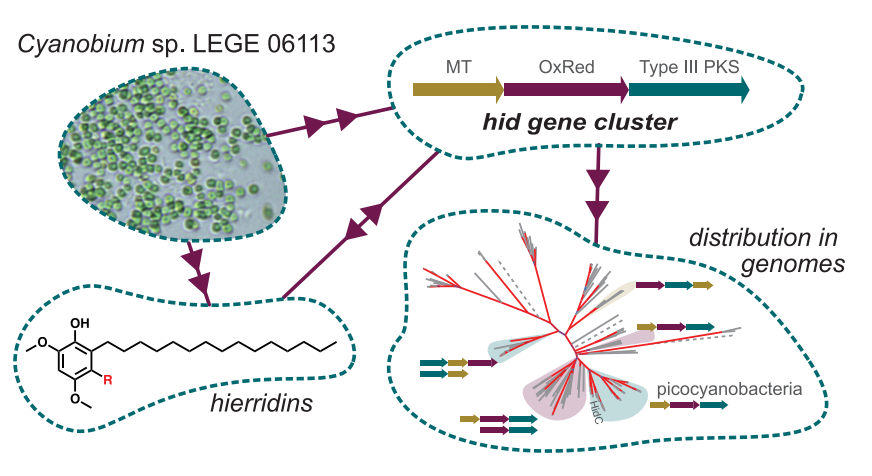

Prochlorococcus, are widespread throughout coastal and open waters around the globe and contribute strongly to primary productivity in the oceans. ${ }^{5}$ These so-called picocyanobacteria have smaller genomes and do not appear to be as rich in secondary metabolite biosynthesis genes, particularly regarding nonribosomal peptides and polyketides. ${ }^{4}$ We have recently reported that the marine picocyanobacterium Cyanobium sp. LEGE 06113 produces the alkylresorcinol hierridin B (1, Figure 1A), ${ }^{6}$ an O-methylated monoalkylresorcinol that features a long $\left(\mathrm{C}_{15}\right)$ aliphatic chain. This metabolite had erological features (e.g. differentiated cells) and have genomes that harbor multiple secondary metabolite biosynthetic gene clusters (BGCs). ${ }^{4}$ Picoplanktonic cyanobacteria, such as those from the genera Synechococcus/Cyanobium and 


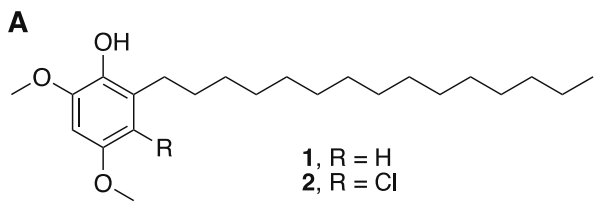

B
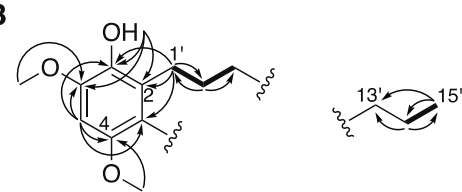

Figure 1. (A) Structures of hierridins B (1) and C (2). (B) Key $\mathrm{HMBC}$ (arrows) and COSY (thick bonds) correlations establishing the partial structures of the aromatic moiety and aliphatic chain terminus of compound 2 .

been previously reported from the filamentous cyanobacterium Leptolyngbya ectocarpii SAG 60.90 and it was active as a mixture (with its $\mathrm{C}_{17}$ alkyl analogue hierridin $\mathrm{A}$ ) against the malaria parasite Plasmodium falciparum. ${ }^{7}$ The only other known cyanobacterial monoalkylresorcinol is cylindrofridin A, a chlorinated intermediate in the biosynthesis of the cylindrocyclophanes originating from a type III PKS pathway. ${ }^{8}$

As part of an effort to reisolate 1, we identified a related chlorinated monoalkylresorcinol, hierridin C (2, Figure 1A), the isolation, structure elucidation, antiplasmodial activity, and a straightforward synthesis of which are reported herein. ${ }^{9}$ To understand the biosynthesis of the hierridins in cyanobacteria, we sequenced and mined the genome of Cyanobium sp. LEGE 06113 to find the hierridin BGC, hid, of a type III PKS nature. We show that this gene cluster is present in a large number of cyanobacterial genomes, most notably those of picocyanobacterial genera abundant in the world's oceans.

\section{RESULTS AND DISCUSSION}

Isolation and Structure Elucidation of Hierridin C (2). With an initial purpose of reisolating hierridin B (1) for biological activity studies, early stationary-phase cultures of Cyanobium sp. LEGE 06113 were harvested and the biomass extracted with $\mathrm{CH}_{2} \mathrm{Cl}_{2}: \mathrm{MeOH}(2: 1)$ as previously described. ${ }^{6}$ The resulting extract was fractionated by a modified version of the normal-phase vacuum liquid chromatography (VLC) protocol employed to isolate hierridin B (1). ${ }^{6}$ The modification consisted of an initial gentle gradient elution step with the purpose of obtaining less-complex hierridin Bcontaining fractions and facilitate the isolation of this metabolite. This was effectively achieved, as revealed by spectroscopic inspection of the fractions obtained by VLC. The ${ }^{1} \mathrm{H}$ NMR spectrum $\left(\mathrm{CDCl}_{3}\right)$ of fraction $\mathrm{A} 1$, eluting with an $87: 13$ mixture of $n$-hexane and EtOAc, exhibited the distinctive methoxy singlets of 1 , resonating at $\delta_{\mathrm{H}} 3.85$ and 3.76 (Figure S1). This fraction was selected for further purification, which was carried out using consecutive semipreparative and analytical-scale RP-HPLC separations, resulting in the isolation of $\mathbf{1}$, as expected, but also of the new metabolite 2 , both in submilligram amounts $(0.5$ and $0.3 \mathrm{mg}$, $0.003 \%$ and $0.002 \%$ dry wt, respectively).

The ${ }^{1} \mathrm{H}$ NMR spectrum of $\mathbf{2}$ in $\mathrm{CDCl}_{3}$ resembled that of $\mathbf{1}{ }^{6}$ Still, a single aromatic proton resonance $\left(\delta_{\mathrm{H}} 6.44\right)$ was observed for 2 , suggesting a pentasubstituted aryl moiety. A combination of $1 \mathrm{D}\left({ }^{1} \mathrm{H},{ }^{13} \mathrm{C}\right.$ ) and $2 \mathrm{D}$ (HSQC, HMBC,
COSY) NMR data for 2 in DMSO- $d_{6}$ (Table 1) revealed the architecture of the aromatic moiety as a 2,3,4,6-substituted

Table 1. NMR Spectroscopic Data $\left({ }^{1} \mathrm{H} 600 \mathrm{MHz},{ }^{13} \mathrm{C} 150\right.$ MHz, DMSO- $d_{6}$ ) for Hierridin C (2)

\begin{tabular}{lllll}
\multicolumn{1}{c}{ no. } & \multicolumn{1}{c}{$\delta_{\mathrm{C}}$, type } & $\delta_{\mathrm{H}}(\mathrm{J}$ in $\mathrm{Hz})$ & \multicolumn{1}{c}{$\mathrm{HMBC}^{a}$} & COSY \\
1 & $138.3, \mathrm{C}$ & & & \\
$1-\mathrm{OH}$ & & $8.30, \mathrm{~s}$ & $1,2,6$ & \\
2 & $128.0, \mathrm{C}$ & & & \\
3 & $112.8, \mathrm{C}$ & & & \\
4 & $147.6, \mathrm{C}$ & & $1,3,4,6$ & \\
5 & $96.6, \mathrm{CH}$ & $6.66, \mathrm{~s}$ & & \\
6 & $146.3, \mathrm{C}$ & & 4 & $2^{\prime}$ \\
7 & $56.4, \mathrm{CH}_{3}$ & $3.77, \mathrm{~s}$ & 6 & $1^{\prime}, 3^{\prime}$ \\
8 & $55.9, \mathrm{CH}_{3}$ & $3.81, \mathrm{~s}$ & $1,2,3,2^{\prime}$ & \\
$1^{\prime}$ & $27.0, \mathrm{CH}_{2}$ & $2.66, \mathrm{t}(7.6)$ & $1^{\prime}, 3^{\prime}-12^{\prime}$ & \\
$2^{\prime}$ & $28.2, \mathrm{CH}_{2}$ & $1.42, \mathrm{~m}$ & $3^{\prime}-12^{\prime}$ & $2^{\prime}$ \\
$3^{\prime}-12^{\prime}$ & $28.7-29.0, \mathrm{CH}_{2}$ & $1.23-1.29, \mathrm{~m}$ & $14^{\prime}$ & $15^{\prime}$ \\
$13^{\prime}$ & $31.3, \mathrm{CH}_{2}$ & $1.23, \mathrm{~m}$ & $13^{\prime}, 15^{\prime}$ & $1^{\prime}$ \\
$14^{\prime}$ & $22.1, \mathrm{CH}_{2}$ & $1.24, \mathrm{~m}$ & $13^{\prime}, 14^{\prime}$ &
\end{tabular}

${ }^{a}$ From proton to indicated carbon.

phenol with an aliphatic chain and two methoxy groups as three of the substituents, confirming its relatedness to metabolite 1 (Figure 1B). Nevertheless, establishing the full structure of 2 required extensive correlational analysis, mostly owing to the determination of substituent arrangement in the aromatic moiety. This was facilitated by HMBC correlations from the aromatic proton $\left(\delta_{\mathrm{H}} 6.66, \mathrm{H}-5\right)$ to four deshielded carbons at $\delta_{\mathrm{C}} 147.6,146.3,138.3$, and 112.8 (C-4, C-6, C-1, and $\mathrm{C}-3$, respectively), suggesting that the carbon resonating at $\delta_{\mathrm{C}} 128.0(\mathrm{C}-2)$ should be para to $\mathrm{H}-5$. The benzylic protons $\left(\delta_{\mathrm{H}} 2.66, \mathrm{H}_{2}-1^{\prime}\right)$ resonance showed correlations to three aromatic carbons at $\delta_{\mathrm{C}} 138.3,128.0$, and 112.8 (C-1, C-2, and $\mathrm{C}-3$, respectively). This allowed assigning the carbons resonating at $\delta_{\mathrm{C}} 147.6(\mathrm{C}-6)$ and $146.3(\mathrm{C}-4)$ as ortho to $\mathrm{H}$ 5 . In addition, each of these carbons was found to have a methoxy substituent, on the basis of HMBC correlations from the methoxy protons at $\delta_{\mathrm{H}} 3.81\left(\mathrm{H}_{3}-8\right)$ and $3.77\left(\mathrm{H}_{3}-7\right)$ to $\mathrm{C}-6$ and $\mathrm{C}-4$, respectively. The final substituent arrangement was established from HMBC correlations between the exchangeable phenol proton $(\mathrm{OH}-1)$ and three carbons at $\delta_{\mathrm{C}} 146.3$, 138.3, and 128.0 (C-6, C-1, and C-2, respectively), leading to the assignment of the hydroxy group to the carbon at $\delta_{\mathrm{C}} 138.3$ (C-1) and of its position as adjacent to both C-6 and C-2. This and the previously assumed constraints resulted in the allocation of the alkyl substituent to the carbon at $\delta_{\mathrm{C}} 128.0$ $(\mathrm{C}-2)$ and subsequent assignment of the carbons resonating at $\delta_{\mathrm{C}} 112.8$ (C-3) and $147.6(\mathrm{C}-4)$ as ortho and meta to C-2, respectively. The partial structure was finalized by the straightforward assignment, on the basis of COSY and HMBC correlations, of the methylene protons resonating at $\delta_{\mathrm{H}} 1.42\left(\mathrm{H}_{2}-2^{\prime}\right)$ as being in an intermediate position between the benzylic methylene and the $\mathrm{CH}_{2}$ envelope. A second partial structure (Figure 1B) was extracted from the NMR data, corresponding to the terminus of an aliphatic chain, and was COSY- and HMBC-correlated to the methylene envelope.

From the NMR data, the substituent at C-3 was unknown and the precise number of $\mathrm{CH}_{2}$ groups in the aliphatic chain difficult to estimate through the integration of the ${ }^{1} \mathrm{H}$ NMR data of 2. These uncertainties were clarified by HRESIMS 
analysis. Despite the low ionization under ESI conditions, using direct infusion we were able to observe an $[\mathrm{M}-\mathrm{H}]^{-}$ion with an $\mathrm{m} / \mathrm{z}$ value of 397.2530 that exhibited a characteristic isotopic pattern for one chlorine atom (Figure S8), corresponding to a molecular formula for the parent compound of $\mathrm{C}_{23} \mathrm{H}_{39} \mathrm{ClO}_{3}$ and thereby establishing the proposed structure for 2 . Because fragmentation of this compound under ESI conditions was limited and uninformative, we resorted to gas chromatography-mass spectrometry (GC-MS/MS) analysis of $\mathbf{2}$ for structural corroboration. A single-chlorine atom isotope pattern for the aromatic "head" following benzylic fragmentation was observed (Figure S9), supporting the proposed structure.

Metabolite $\mathbf{2}$ is structurally related to a small number of previously reported chlorinated monoalkylresorcinols from the eukaryotic realm. The halogenated 5-methylresorcinol derivative 4-chloroorcinol was isolated from the phytopathogenic fungus Colletotrichium higgisianum and induced chlorosis in plant leaves, inhibited seed germination, and was also toxic to the crustacean Artemia salina. ${ }^{10}$ The monochasiols are a series of long-chain alkylresorcinols, with a single chlorinated carbon in between the resorcinol hydroxy groups, that have been isolated from the slime mold Dictyostelium and have mild immunosuppressive activity. ${ }^{11}$ Other examples include a series of dimerized chlorinated short-chain alkylresorcinols-the spiromastols - that have been reported recently from a deepsea fungus and have antibacterial activity. ${ }^{12}$

Biological Activity of Hierridin C (2). Taking into account the bioactivity profile of $\mathbf{1}$, with negligible toxicity to human cell lines (showing only a mild selective activity toward HT-29 cancer cells) ${ }^{6}$ and low micromolar antiplasmodial activity, ${ }^{7}$ we decided to evaluate the cancer cell line cytotoxicity and antimalarial activity of 2 . Upon exposure of human cancer cell lines to up to $30 \mu \mathrm{g} \mathrm{mL}^{-1}(75 \mu \mathrm{M})$ of 2 , no cytotoxicity was observed (Figure S10). Both 1 and 2 were tested for in vitro activity against Plasmodium falciparum (3D7 strain and the chloroquine-resistant $\mathrm{Dd} 2$ strain). While all $\mathrm{IC}_{50}$ values obtained were in the low-micromolar range (Figure S11), compound 2 was slightly more potent than 1 against the $3 \mathrm{D} 7$ strain $\left(\mathrm{IC}_{50}\right.$ values of $1.5 \pm 0.1$ and $2.1 \pm 0.1 \mu \mathrm{M}$, respectively). The two metabolites showed equal potency toward the $\mathrm{Dd} 2$ strain $\left(\mathrm{IC}_{50}=2.3 \pm 0.7 \mu \mathrm{M}\right.$ for 2 and $2.3 \pm$ $0.1 \mu \mathrm{M}$ for 1 ). Thus, the presence of the chlorine atom seems to have a marginal influence on the antiplasmodial activity.

Total Synthesis of Hierridin C (2). The low yields of 1 and 2 obtained from Cyanobium sp. LEGE 06113 cultures and their relatively simple and planar structures motivated our efforts toward synthesizing these compounds in an expeditious and convenient fashion, as a means to enable future biosynthetic and biological activity studies. We envisioned that the most straightforward synthetic route to the preparation of $\mathbf{2}$ would be from aromatic electrophilic chlorination of $\mathbf{1}$. A previous synthetic procedure for obtaining a longer-chain analogue of $\mathbf{1}$ was available in the literature ${ }^{13}$ but did not work in our hands. Therefore, we designed a convenient synthetic route to its preparation (Scheme 1, A) using the commercially available suitable aromatic ring moiety 2-hydroxy-3,5-dimethoxybenzaldehyde (3), which can also be easily prepared from 3,5-dimethoxybenzaldehyde. ${ }^{14,15}$

Grignard addition to 3 using commercial tetradecylmagnesium chloride afforded the corresponding carbinol 4 smoothly in high yields (86\%). Reduction of the $\alpha$-hydroxy group is already described in the literature for the monomethoxylated
Scheme 1. (A) Synthesis of Hierridin B (1); (B) Synthesis of Hierridin $\mathrm{C}(2)^{a}$

A

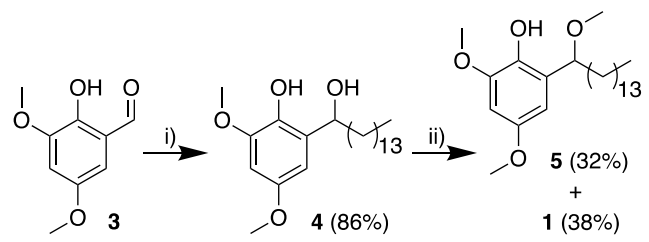

B

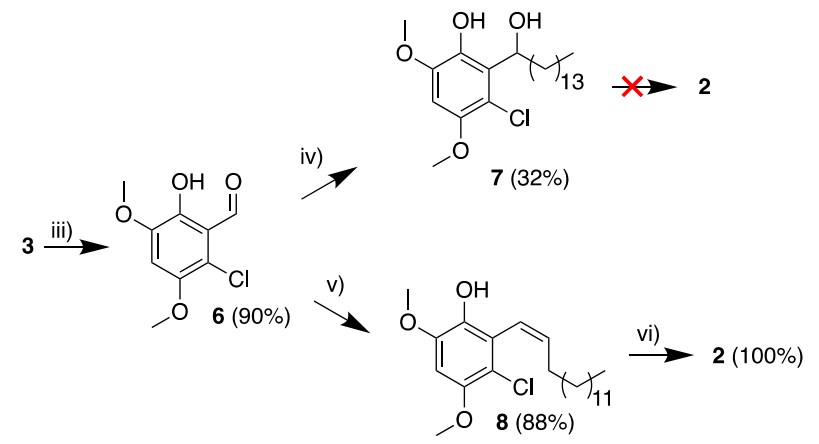

${ }^{a}$ Conditions: (i) tetradecylmagnesium chloride, THF, $2 \mathrm{~h}, \mathrm{rt}$; (ii) $\mathrm{H}_{2} \mathrm{SO}_{4}, \mathrm{MeOH}, \mathrm{Pd} / \mathrm{C} 10 \%$ (w/w), $\mathrm{H}_{2}$ (1 atm), $80{ }^{\circ} \mathrm{C}$; (iii) NCS, $\mathrm{HCl} 37 \%, 15$ min, rt; (iv) tetradecylmagnesium chloride, THF, $2 \mathrm{~h}$, rt; (v) Wittig reaction: myristyltriphenylphosphonium bromide, $n-\mathrm{BuLi}$, THF, rt; (vi) Pd/C 10\% (w/w), $\mathrm{H}_{2}$ (1 atm), EtOAc, $0{ }^{\circ} \mathrm{C}$.

counterpart (o-vanillin derivative). ${ }^{13}$ Applying the same protocol for derivative 4 using $\mathrm{MeOH}$ as solvent (due to solubility issues) afforded $\mathbf{1}$ in moderate yields, in contrast with the results described in the literature for the monomethoxylated parent. ${ }^{13} \mathrm{We}$ found that this protocol led to the formation of an ether at the $\alpha$-benzylic position as a side product (5), which can be explained by methanol trapping of the intermediate carbocation in acidic medium. An additional methoxy group seems to influence the outcome of the reaction, as no formation of ether side products was reported by the authors.

We predicted that monochlorination at carbon 3 of the aromatic ring in $\mathbf{1}$ would be a bottleneck step for the preparation of 2 , because it is highly activated by the presence of electron-donating groups, which might end up competing with 3,5-dichlorinated and/or 3- and 5-monochlorinated products. Our attempts at this reaction were unfruitful using standard procedures commonly used for monohalogenation of phenol derivatives. Using $\mathrm{NaClO} / \mathrm{NaOH}^{16}$ no reaction took place, and NCS-assisted chlorination ${ }^{17}$ yielded an uncharacterized polychlorinated adduct. Thus, we considered monochlorination of the salicylaldehyde derivative 3 prior to the Grignard addition protocol. An analogous strategy was used, for example, in the syntheses of certain monochasiols. ${ }^{11}$ Following a standard chlorination protocol using 1 equiv of NCS in the presence of 0.1 equiv of $p$-toluenesulfonic acid $(\mathrm{TsOH}),{ }^{17}$ no traces of 6 were detected after $6 \mathrm{~h}$. Surprisingly, replacement of $\mathrm{TsOH}$ by concentrated $\mathrm{HCl}$ afforded $\mathbf{6}$ in very good yield $(>90 \%)$ in a short reaction time $(15 \mathrm{~min})$ (Scheme $1, \mathrm{~B})$. Despite the high aromatic ring activation in compound 3 , the electrophilic chlorination revealed total regioselectivity (see NOESY experiment, Figure S23). Still, we were unable to obtain compound $\mathbf{2}$ following $\alpha$-hydroxy elimination of the 
A
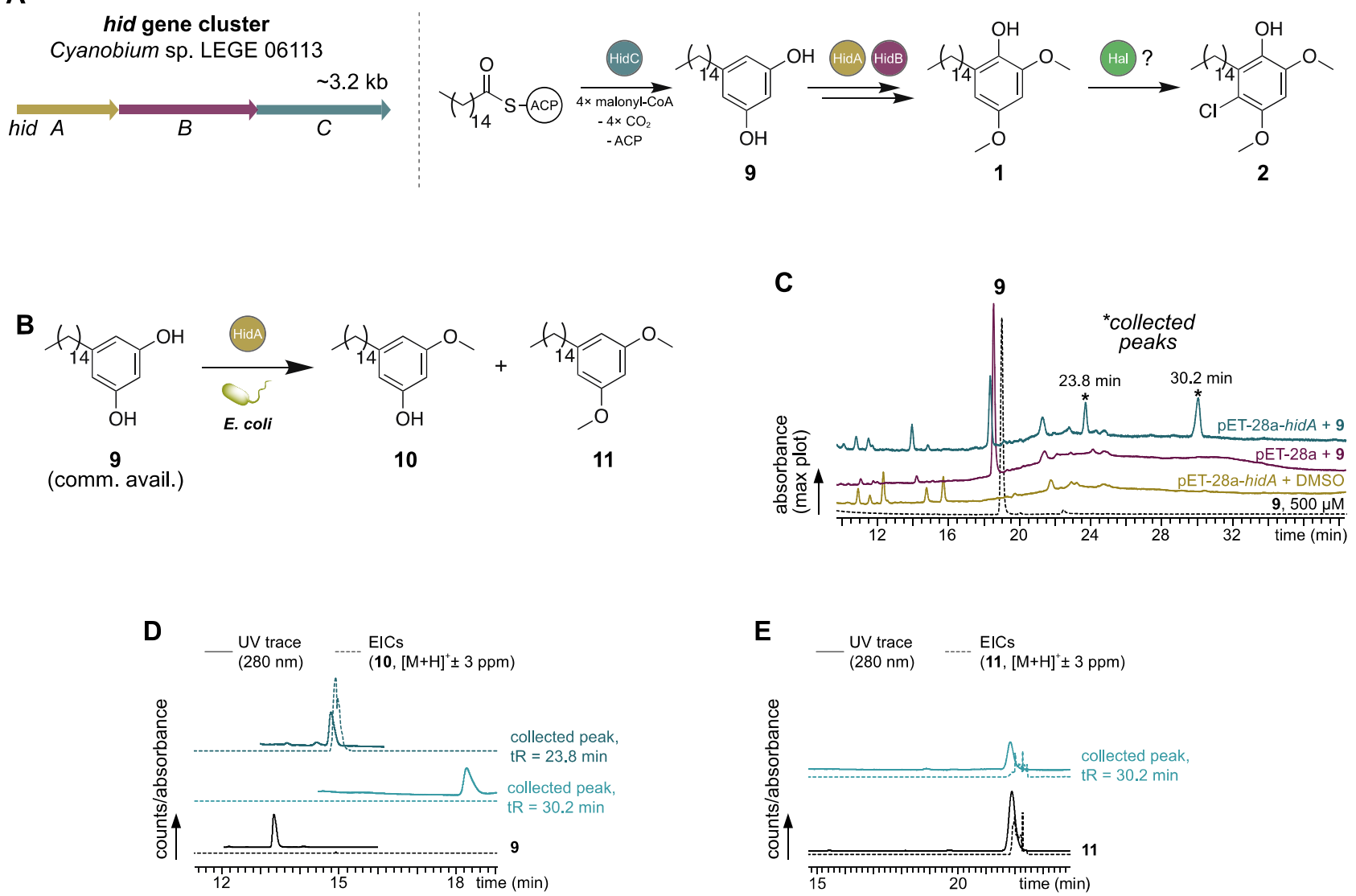

Figure 2. Hierridin biosynthesis in Cyanobium sp. LEGE 06113. (A) Overview of the hierridin biosynthetic gene cluster (hid) organization and proposed biosynthesis of hierridins (Hal, putative halogenase). (B) Schematic representation of the experimental approach to test whether HidA methylates an alkylresorcinol substrate in hierridin biosynthesis. (C) HPLC-PDA analysis of E. coli expressing the hidA gene, with two new peaks eluting at 23.8 and $30.2 \mathrm{~min}$. (D) LC-HRESIMS analysis of the two chromatographic peaks identified from HPLC-PDA analysis, indicating that an $\mathrm{m} / z$ value consistent with compound $\mathbf{1 0}$ is observed for one of the peaks. (E) LC-HRESIMS analysis of the collected peak eluting at 30.2 min, showing the same retention time as a standard of compound 11 obtained by synthesis and an $\mathrm{m} / z$ value consistent with the protonated species ([M $+\mathrm{H}]^{+}$) of 11 .

Grignard addition product 7 (Scheme 1, B); see Supporting Information for details).

To overcome this hurdle, we considered a Wittig olefination for the introduction of the alkyl chain and subsequent saturation of the olefin by catalytic hydrogenation (Scheme 1, B). The appropriate Wittig reagent was prepared by refluxing 1-bromotetradecane with triphenylphosphine, affording the corresponding phosphonium salt, which was recrystallized in $\mathrm{Et}_{2} \mathrm{O}$. The Wittig reagent was then treated with $n$-BuLi in tetrahydrofuran (THF) followed by addition of salicylaldehyde $\mathbf{6}$, affording the $(Z)$-alkene $\mathbf{8}$ in good yield (88\%). Hydrogenation of 8 using catalytic amounts of $\mathrm{Pd} / \mathrm{C} 10 \%$ in EtOAc at $0{ }^{\circ} \mathrm{C}$ proceeded smoothly, yielding hierridin $\mathrm{C}$ (2) quantitatively in $1 \mathrm{~h}$. Compound 2 can thus be efficiently obtained in just three steps $(3 \rightarrow 6 \rightarrow 8 \rightarrow 2)$ in high total yield $(80 \%)$.

Discovery of the Hierridin Biosynthetic Gene Cluster (hid). Despite a number of reports on the biological activity of extracts from members of the picocyanobacteria (Synechococcus/Cyanobium/Procholorococcus), ${ }^{18,19}$ this phylogenetically congruent group is notoriously lacking in PKS or NRPS biosynthetic genes. ${ }^{4}$ We had previously proposed that a type III PKS could give origin to the alkylresorcinol moiety, ${ }^{6}$ based on the biosynthesis of cyanobacterial cylindrocyclophane monomers $^{20}$ or of other prokaryotic alkylresorcinols. ${ }^{21}$ In a previous effort using degenerate primers designed to target then-available type III PKS genes from cyanobacteria, we failed to PCR-amplify a homologue from Cyanobium sp. LEGE 06113. ${ }^{6}$

We envisioned that a genome-mining strategy could yield better results and sequenced the genome of this cyanobacterium, having obtained $2.6 \mathrm{Mbp}$ distributed over 30 contigs. The genome data were searched for homologues of the type III PKS cylI from Cylindrospermum licheniforme UTEX B 2014 (involved in cylindrocyclophane biosynthesis) ${ }^{20}$ using BlastP. A single homologue (27\% identity, $42 \%$ similarity) was found, located in a $\sim 387 \mathrm{~kb}$ contig. Annotation of the genomic context of this type III PKS homologue (Table S1) revealed genes with predicted functions consistent with hierridin structural features (one methyltransferase and one hydroxylase). Based on the analysis of predicted open reading frames, this putative hierridin BGC (hid) is proposed to comprise at least hidA, encoding a SAM-dependent methyltransferase; hidB, coding for a FixC superfamily FAD-dependent oxidoreductase and the type III PKS-encoding hidC (Figure 2A). A PAP-fibrillin is encoded downstream of this proposed minimal hid gene cluster, but its relation to the hid genes is unclear at this stage. 


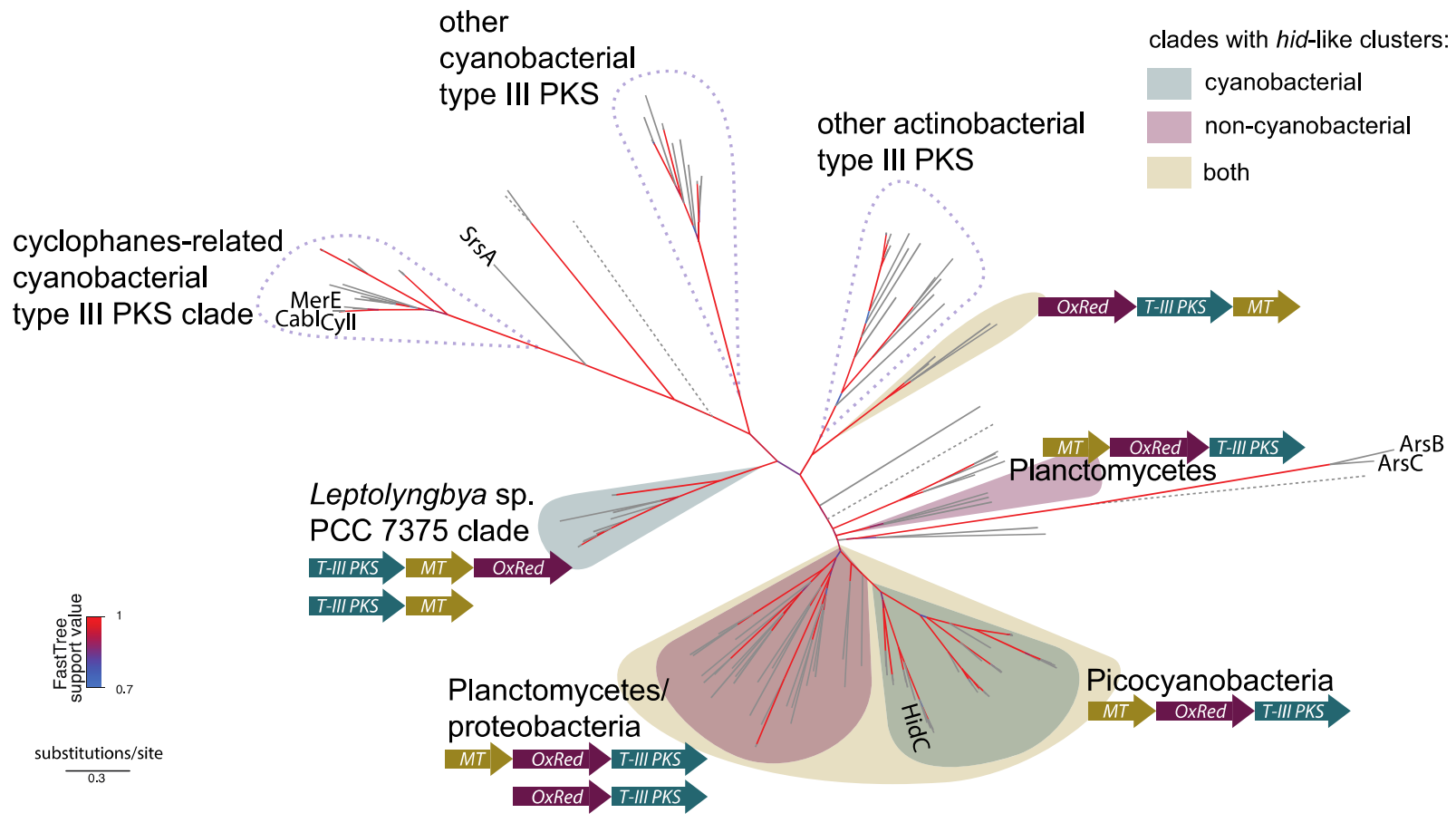

Figure 3. Distribution of hid-like gene clusters among bacteria. FastTree 2 (approximately maximum-likelihood) phylogeny of bacterial homologues of HidC, highlighting clades dominated by type III PKS enzymes that are encoded in clusters with the same general architecture of the hid gene cluster, i.e., those putatively coding for an additional SAM-dependent methyltransferase (MT) and a FAD-dependent oxidoreductase (OxRed). In the highlighted clades, the organization of clusters lacking either the MT or the OxRed are also shown. Dotted branches correspond to cyanobacterial type III PKSs that do not fall within the highlighted clades.

To experimentally confirm the involvement of the hid gene cluster in the biosynthesis of the hierridins, we initially attempted to clone and express the entire cluster in E. coli BL21 cells, but were unable to observe any protein overexpression by gel electrophoresis or any differential metabolite profile by HPLC analysis. Because the hidA gene encodes a methyltransferase that does not contain an ICMT (isoprenylcysteine carboxyl methyltransferase) domain, we envisaged that HidA was not required for decarboxylation of the aromatized product of $\mathrm{HidC}^{22}$ and that its natural substrate could be the alkylresorcinol 9 (Figure 2B). The latter compound is commercially available, which presented an opportunity to test the ability of HidA to methylate this substrate and confirm the involvement of the hid BGC in hierridin production. In fact, E. coli BL21 cells carrying an expression vector with an $\mathrm{N}-\mathrm{His}_{6}$-HidA construct and grown in the presence of 9 produced at least two new compounds compared to an empty vector control (Figure 2C). One of these compounds presented an HRESIMS-derived $m / z$ value consistent with the monomethylated alkylresorcinol 10 (Figure 2D). The other compound, eluting later in reversed-phase conditions (Figure 2C,D), was found to correspond to the dimethylated alkylresorcinol $\mathbf{1 1}$ by comparison of its LCHRESIMS elution profile with that of synthetic 11 (Figure $2 \mathrm{E}$ ), obtained by methylation of 9 using dimethylsulfate.

Curiously, the hid gene cluster does not contain a halogenase nor could one be found among the genome data of this cyanobacterium through Blast searches using the sequences of the flavin-dependent halogenases ChlA (that acts on phenolic rings), ${ }^{23}$ RebH or KtzR (that chlorinate tryptophan), ${ }^{24}$ or those of members of other halogenase classes $^{24}$ as queries. Interestingly, no halogenase was found in the genome of Synechocystis salina LEGE 06155 that could explain an analogous halogenation in the biosynthesis of bartoloside D. ${ }^{25}$ Because Cyanobium sp. LEGE 06113 is not axenic, we repeated these searches using the whole set of contigs (cyanobacterial and non-cyanobacterial) obtained from the genome (in fact a minimetagenome) sequencing data. Although ChlA homologues were not found in these data, three RebH/KtzR homologues were present in alphaproteobacterial contigs (see Table S2 for details). This raises the possibility for the noncyanobacterial conversion of $\mathbf{1}$ into 2 . Still, exposure of compound $\mathbf{1}$ to a lysate of a Cyanobium sp. LEGE 06113 culture did not lead to any observable conversion to metabolite 2 (not shown); therefore the nature of the halogenation event remains unclear.

Distribution of the hid Gene Cluster among Cyanobacterial Genomes. The occurrence of hierridin B in phylogenetically distant cyanobacteria from the Cyanobium and Leptolyngbya genera ${ }^{6}$ suggests that the hid gene cluster could be widely distributed in the cyanobacterial tree of life. BlastP searches, using the amino acid sequence of HidC as query against the NCBI database, revealed an elevated number of close homologues, found mostly among Cyanobacteria, but also in Planctomycetes and Proteobacteria. Many of these homologues were part of hid-like clusters, i.e., containing a FAD-dependent oxidoreductase and a SAM-dependent methyltransferase. To obtain a clearer picture of the distribution of these clusters in the Cyanobacteria phylum we retrieved and aligned the sequences of the top HidC homologues identified from BlastP searches (we retrieved a total of 149 sequences of top Blast hits from searches limited and not limited to cyanobacterial sequences), together with the amino acid sequences of the alkylresorcinol-generating SrsA, ArsB, and ArsC type III PKSs. A phylogenetic analysis of the resulting alignment revealed that several well-supported groups encoded 
homologues of HidC. A majority of these homologues were encompassed in a major phylogenetic clade composed of picocyanobacterial as well as other bacterial type III PKSs that were part of hid-like gene clusters (Figure 3 and Figure S13). Within this larger clade, HidC and picocyanobacterial HidC homologues from strains belonging to the genera Prochlorococcus, Synechococcus, Cyanobium, Vulcanococcus, and Aphanothece formed a well-supported independent subclade. In fact, the picocyanobacterial HidC homologues were encoded within hidABC gene clusters, while in the sister group of HidC homologues from proteobacteria and planctomycetes, these were encoded in gene clusters with either hidABC or hidBC architectures. The genomes of filamentous cyanobacteria closely related to the hierridin-producing Leptolyngbya ectocarpi SAG 60.90 encoded HidC homologues that constituted a separate clade in the resulting phylogenetic tree; these were mostly found within hidCAB or hidCA gene cluster architectures. Overall, hid-like gene clusters seem to be prevalent within certain cyanobacterial phylogenetic groups, most notably picocyanobacteria, which contrasts with the small number of alkylresorcinols reported from these organisms.

\section{CONCLUSIONS}

Our investigations of hierridin-like alkylresorcinol biosynthesis in cyanobacteria suggest that these metabolites are prevalent in the world's oceans. Because many of the strains that harbor hid gene clusters are picoplanktonic unicellular cyanobacteria with a major primary production impact in the world's oceans, the natural role of these compounds and associated ecological implications deserve further study. Phenolic lipids structurally related to hierridins interact with biological membranes ${ }^{26}$ with known implications in encystment ${ }^{21}$ and antibacterial resistance, ${ }^{27}$ and it is possible that hierridins play similar role(s) in cyanobacteria, despite their low abundance in Cyanobium sp. LEGE 06113. On the other hand, also noteworthy is the similarity of hierridins to the chlorinated hexaphenones DIF (Differentiation-Inducing Factor)-1, DIF-2, and DIF- $3^{28}$ and to MPBD (4-methyl-5-pentylbenzene-1,3-diol), ${ }^{29}$ all of which are associated with developmental signaling in the slime mold Dictyostelum. Therefore, it is also conceivable that hierridins have evolved to carry out a signaling or interference role in the aquatic medium. In any case, our straightforward synthesis of the hierridins will facilitate future experimental explorations of these scarce metabolites, in particular of their biological function and antimalarial properties.

\section{EXPERIMENTAL SECTION}

General Experimental Procedures. Melting points were determined using a Stuart Scientific Bibby apparatus and are uncorrected. UV spectra were acquired on a Spectramax spectrophotometer (Molecular Devices). NMR spectra were recorded on a 400 $\mathrm{MHz}$ spectrometer (Avance III, Bruker) and on a $600 \mathrm{MHz}$ spectrometer equipped with a $5 \mathrm{~mm}$ cyroprobe (Avance III HD, Bruker). $\mathrm{CDCl}_{3}$ or DMSO- $d_{6}$ was used as solvent, and the chemical shifts are reported relative to residual $\mathrm{CHCl}_{3}\left(\delta_{\mathrm{H}} 7.26, \delta_{\mathrm{C}} 77.16\right)$ or DMSO $\left(\delta_{\mathrm{H}} 2.50, \delta_{\mathrm{C}} 39.52\right)$, respectively. HRESIMS data of pure 2 were acquired on an LTQ Orbitrap XL spectrometer, controlled by LTQ Tune Plus 2.5.5 and Xcalibur 2.1 (Thermo Scientific). The capillary voltage of the ESI was set to $-3000 \mathrm{~V}$. The capillary temperature was $275^{\circ} \mathrm{C}$. The sheath gas flow rate (nitrogen) was set to 40 units. The capillary voltage was $-35 \mathrm{~V}$, and the tube lens voltage $-200 \mathrm{~V}$. Samples were injected at a concentration of approximately $50 \mu \mathrm{g} / \mathrm{mL}$. The same instrument and analysis were used for synthetic compound characterization (with the exception of compound 11, for which the HRESIMS spectrum was retrieved from LC-HRESIMS analysis; see Heterologous Expression of hidA in E. coli and Metabolite Profiling section for details), but the ESI capillary voltage was $-3100 \mathrm{~V}$ (capillary temperature was $275^{\circ} \mathrm{C}$ ), sheath gas was set at 5 units, and the capillary voltage was set at $-40 \mathrm{~V}$ with a tube lens voltage set at $-157 \mathrm{~V}$ ). Both semipreparative and analytical-scale RPHPLC for the isolation of hierridin $\mathrm{C}$ were performed using a system composed of a 1525 pump module and a $2485 \mathrm{UV}$-vis detector (Waters) and using HPLC-grade solvents. All other solvents used were ACS grade. GC-MS analysis was performed as reported previously for $1,{ }^{6}$ using a TRACE GC Ultra (Thermo Scientific) gas chromatograph coupled with a Polaris $\mathrm{Q}$ ion trap mass spectrometer. The system included an AS-3000 autosampler. A ZBXLB capillary column $(30 \mathrm{~m} \times 0.25 \mathrm{~mm} \times 0.25 \mu \mathrm{m})$ from Phenomenex was selected for chromatographic separation. Ultrapure grade helium was used as a carrier gas (flow $1.0 \mathrm{~mL} \mathrm{~min}{ }^{-1}$ ). For the synthesis of hierridins, all chemicals were of reagent grade and were used without further purification: tetradecylmagnesium chloride solution $1 \mathrm{M}$ in THF (CAS: 110220-87-6, Aldrich) and 2-hydroxy3,5-dimethoxybenzaldehyde (97\% purity, CAS: 65162-29-0, Fluorochem). All reactions were carried out under an argon atmosphere. Analytical TLC was carried out on precoated silica gel plates (Merck $60 \mathrm{~F} 254,0.25 \mathrm{~mm}$ ) using UV light and an ethanolic solution of phosphomolybdic acid (followed by gentle heating) for visualization.

Biological Material. The cyanobacterium Cyanobium sp. LEGE 06113 was obtained from the LEGEcc. ${ }^{30}$ The strain was cultured in 6 $\mathrm{L}$ flasks each with $4 \mathrm{~L}$ of $\mathrm{Z} 8$ medium $^{31}$ supplemented with $20 \mathrm{~g} \mathrm{~L}^{-1}$ $\mathrm{NaCl}$, under constant sterile aeration and a light (photon irradiance $\sim 30 \mu \mathrm{mol} \mathrm{m} \mathrm{m}^{-2} \mathrm{~s}^{-1}$ )/dark cycle of 14:10 h. Temperature was maintained at $26^{\circ} \mathrm{C}$. When cultures reached late exponential phase $(6$ to 8 weeks postinoculation), cyanobacterial cells were harvested by centrifugation and rinsed with deionized $\mathrm{H}_{2} \mathrm{O}$. The biomass was then freeze-dried and kept at $-20{ }^{\circ} \mathrm{C}$ until extraction.

Isolation of Hierridin C (2). Freeze-dried cells from Cyanobium sp. LEGE 06113 (16.0 g, dry wt) were extracted repeatedly with a warm $\left(<40{ }^{\circ} \mathrm{C}\right)$ mixture of $\mathrm{CH}_{2} \mathrm{Cl}_{2} / \mathrm{MeOH}(2: 1)$. The resulting slurry was filtered through Whatman grade 1 qualitative filter paper (GE Healthcare Life Sciences) and concentrated in a rotary evaporator to yield $2.58 \mathrm{~g}$ of organic extract. This was fractionated by vacuum liquid chromatography (VLC) using silica gel $60(0.015-$ $0.040 \mathrm{~mm}$, Merck $\mathrm{KGaA}$ ) as stationary phase. Four fractions (A, A1, $A 2$, and A3) were initially collected using 9:1, 87:13, 17:3, and 41:9 mixtures ( $n$-hexane/EtOAc), respectively, as mobile phases. A steeper mobile-phase gradient was then applied to the column, from 4:1 ( $n$ hexane/EtOAc) to $100 \% \mathrm{EtOAc}$ and then to $100 \% \mathrm{MeOH}$, resulting in eight additional fractions. Fraction A1 $(20.4 \mathrm{mg})$ was further fractionated by semipreparative RP-HPLC with a Luna C18 column $(10 \mu \mathrm{m}, 250 \times 10 \mathrm{~mm}$, Phenomenex $)$ under isocratic conditions ( $97 \%$ aqueous $\mathrm{MeCN}, 3 \mathrm{~mL} \mathrm{~min}{ }^{-1}$ ). A chromatographic peak eluting at $t_{\mathrm{R}}=27.1 \mathrm{~min}$ was collected and found to contain 1 as a major constituent. The sample was reinjected into the HPLC system fitted with the above-mentioned column and further separated isocratically, using $90 \% \mathrm{MeCN}(\mathrm{aq})$ as mobile phase. Pure $1(0.5 \mathrm{mg})$ eluted at $41.5 \mathrm{~min}$, and an additional peak eluting at $50.7 \mathrm{~min}$ was collected. The ${ }^{1} \mathrm{H}$ NMR $\left(\mathrm{CDCl}_{3}, 400 \mathrm{MHz}\right)$ of this latter peak showed a major constituent with a set of resonances that indicated relatedness to compound 1. An additional round of analytical-scale HPLC with a Synergi Fusion-RP column $(4 \mu \mathrm{m}, 250 \times 4.6 \mathrm{~mm}$, Phenomenex $)$ and using isocratic elution with $85 \% \mathrm{MeCN}(\mathrm{aq})$ afforded $2\left(t_{\mathrm{R}}=38.9\right.$ $\mathrm{min})$ as a white, amorphous solid (0.3 $\mathrm{mg})$.

Hierridin C (2): white, amorphous solid; UV/vis $(\mathrm{MeOH}) \lambda_{\max }(\log$ ع) 211 (3.0), 249 (2.3), 271 (2.2), 281 (2.2) nm; ${ }^{1} \mathrm{H}$ and ${ }^{13} \mathrm{C}$ NMR Table 1; HRMS $m / z 397.2523[\mathrm{M}-\mathrm{H}]^{-}$(calcd for $\mathrm{C}_{23} \mathrm{H}_{38} \mathrm{ClO}_{3}{ }^{-}$, 397.2515).

Chemical Synthesis Procedures and Characterization Data. Experimental Procedures. 4,6-Dimethoxy-2-(1hydroxypentadecyl)phenol (4). In a round-bottom flask compound $3(100.5 \mathrm{mg}, 0.5516 \mathrm{mmol})$ was dissolved in anhydrous THF $(20$ $\mathrm{mL}$ ) followed by addition of Grignard reagent (tetradecylmagnesium chloride $1.0 \mathrm{M}$ in THF) $(1.1 \mathrm{~mL}, 1.1 \mathrm{mmol})$, and the resulting 
solution was left under stirring for $2 \mathrm{~h}$. The solution was then concentrated in vacuo, and to the residue was added a saturated solution of $\mathrm{NH}_{4} \mathrm{Cl}(20 \mathrm{~mL})$ and $\mathrm{Et}_{2} \mathrm{O}(20 \mathrm{~mL})$. The phases were then separated in a separatory funnel, and the organic phase was washed with deionized $\mathrm{H}_{2} \mathrm{O}(3 \times 20 \mathrm{~mL})$. The organic extract was dried over anhydrous $\mathrm{Na}_{2} \mathrm{SO}_{4}$, filtered, and concentrated in vacuo. The desired compound was then induced to precipitate from the crude oil using $n$ hexane. The solid was filtered and washed with fresh portions of $n$ hexane, affording $4(180.5 \mathrm{mg}, 86 \%)$ as a yellowish solid: $\mathrm{mp}=77-78$ ${ }^{\circ} \mathrm{C} ;{ }^{1} \mathrm{H}$ NMR $\left(\mathrm{CDCl}_{3}, 400 \mathrm{MHz}\right) \delta_{\mathrm{H}} 6.40(\mathrm{~d}, 1 \mathrm{H}, J=2.8 \mathrm{~Hz}, \mathrm{H}-5)$, $6.37(\mathrm{~d}, 1 \mathrm{H}, J=2.8 \mathrm{~Hz}, \mathrm{H}-3), 5.89(\mathrm{~s}, 1 \mathrm{H}, \mathrm{OH}), 4.85(\mathrm{dt}, 1 \mathrm{H}, J=7.6$ $\left.\mathrm{Hz}, 5.6 \mathrm{~Hz}, \mathrm{H}_{-1}^{\prime}\right), 3.85\left(\mathrm{~s}, 3 \mathrm{H}, \mathrm{OCH}_{3}\right), 3.76\left(\mathrm{~s}, 3 \mathrm{H}, \mathrm{OCH}_{3}\right), 2.57$ (d, $1 \mathrm{H}, J=5.4 \mathrm{~Hz}, \mathrm{OH}), 1.88-1.71\left(\mathrm{~m}, 2 \mathrm{H}, \mathrm{H}-2^{\prime}\right), 1.53-1.21(\mathrm{~m}, 24 \mathrm{H}$, $\left.\mathrm{H}-3^{\prime}-\mathrm{H}-14^{\prime}\right), 0.88\left(\mathrm{t}, 3 \mathrm{H}, J=6.8 \mathrm{~Hz}, \mathrm{H}-15^{\prime}\right) ;{ }^{13} \mathrm{C}$ NMR $\left(\mathrm{CDCl}_{3}, 101\right.$ $\mathrm{MHz}) \delta_{\mathrm{C}} 153.2(\mathrm{C}, \mathrm{C}-4), 147.4$ (C, C-6), 137.2 (C, C-1), 130.0 (C, C-2), $102.5(\mathrm{CH}, \mathrm{C}-3), 98.4(\mathrm{CH}, \mathrm{C}-5), 72.0\left(\mathrm{CH}, \mathrm{C}-1^{\prime}\right), 56.2\left(\mathrm{CH}_{3}\right.$, $\left.\mathrm{OCH}_{3}\right)$, $55.9\left(\mathrm{CH}_{3}, \mathrm{OCH}_{3}\right), 37.4\left(\mathrm{CH}_{2}, \mathrm{C}-2^{\prime}\right), 32.1\left(\mathrm{CH}_{2}, \mathrm{C}-3^{\prime}\right)$, [29.8 $\left(\mathrm{CH}_{2}\right), 29.8\left(\mathrm{CH}_{2}\right), 29.8\left(\mathrm{CH}_{2}\right), 29.7\left(\mathrm{CH}_{2}\right), 29.7\left(\mathrm{CH}_{2}\right), 29.5$ $\left.\left(\mathrm{CH}_{2}\right), \mathrm{C}-4^{\prime}-\mathrm{C}-13^{\prime}\right], 22.8\left(\mathrm{CH}_{2}, \mathrm{C}-14^{\prime}\right), 14.2\left(\mathrm{CH}_{3}, \mathrm{C}-15^{\prime}\right)$; HRESIMS $m / z$ 379.2885 $[\mathrm{M}-\mathrm{H}]^{-}$(calcd for $\mathrm{C}_{23} \mathrm{H}_{39} \mathrm{O}_{4}{ }^{-}$, 379.2854).

4,6-Dimethoxy-2-pentadecylphenol (Hierridin B, 1). In a roundbottom flask compound $4(108.0 \mathrm{mg}, 0.2838 \mathrm{mmol})$ was dissolved in $\mathrm{MeOH}(20 \mathrm{~mL})$ and hydrogenated via balloon for $3 \mathrm{~h}$ at room temperature (rt) in the presence of $\mathrm{Pd} / \mathrm{C} 10 \%(\mathrm{w} / \mathrm{w})$ and $\mathrm{H}_{2} \mathrm{SO}_{4} 1 \mathrm{M}$ $(0.2 \mathrm{~mL})$. The suspension was filtered over a Celite pad, and the filtrate was concentrated in vacuo. The residue was then chromatographed using $\mathrm{CH}_{2} \mathrm{Cl}_{2}$, affording $1(39.3 \mathrm{mg}, 38 \%)$ and $5(35.8 \mathrm{mg}$, $32 \%)$ as white, amorphous solids. Hierridin $\mathrm{B}(1): \mathrm{mp}=70-72{ }^{\circ} \mathrm{C}$; ${ }^{1} \mathrm{H}$ NMR $\left(\mathrm{CDCl}_{3}, 400 \mathrm{MHz}\right) \delta_{\mathrm{H}} 6.36(\mathrm{~d}, 1 \mathrm{H}, J=2.8 \mathrm{~Hz}, \mathrm{H}-5), 6.29$ $(\mathrm{d}, 1 \mathrm{H}, J=2.8 \mathrm{~Hz}, \mathrm{H}-3), 5.26(\mathrm{br} \mathrm{s}, 1 \mathrm{H}, \mathrm{OH}), 3.85\left(\mathrm{~s}, 3 \mathrm{H}, \mathrm{OCH}_{3}\right)$, $3.76\left(\mathrm{~s}, 3 \mathrm{H}, \mathrm{OCH}_{3}\right), 2.68-2.53\left(\mathrm{~m}, 2 \mathrm{H}, \mathrm{H}-1^{\prime}\right), 1.61(\mathrm{dt}, 2 \mathrm{H}, J=15.4$, $\left.7.5 \mathrm{~Hz}, \mathrm{H}-2^{\prime}\right), 1.38-1.25\left(\mathrm{~m}, 24 \mathrm{H}, \mathrm{H}-3^{\prime}-\mathrm{H}-14^{\prime}\right), 0.89(\mathrm{t}, 3 \mathrm{H}, J=6.9$ $\left.\mathrm{Hz}, \mathrm{H}-15^{\prime}\right) ;{ }^{13} \mathrm{C}$ NMR $\left(\mathrm{CDCl}_{3}, 101 \mathrm{MHz}\right) \delta_{\mathrm{C}} 152.9$ (C, C-4), 146.8 (C, C-6), 137.7 (C, C-1), 128.9 (C, C-2), 105.9 (CH, C-3), 96.8 (CH, C-5), $56.1\left(\mathrm{CH}_{3}, \mathrm{OCH}_{3}\right), 55.9\left(\mathrm{CH}_{3}, \mathrm{OCH}_{3}\right), 32.1\left(\mathrm{CH}_{2}, \mathrm{C}-\right.$ $\left.1^{\prime}\right), 30.2\left(\mathrm{CH}_{2}, \mathrm{C}-2^{\prime}\right),\left[30.0\left(\mathrm{CH}_{2}\right), 29.8\left(\mathrm{CH}_{2}\right), 29.8\left(\mathrm{CH}_{2}\right), 29.7\right.$ $\left.\left(\mathrm{CH}_{2}\right), 29.5\left(\mathrm{CH}_{2}\right), 22.8\left(\mathrm{CH}_{2}\right), \mathrm{C}-3^{\prime}-\mathrm{C}-14^{\prime}\right], 14.3\left(\mathrm{CH}_{3}, \mathrm{C}-15^{\prime}\right)$.

4,6-Dimethoxy-2-(1-methoxypentadecyl)phenol (5). $\mathrm{Mp}=51-$ $53{ }^{\circ} \mathrm{C}$; ${ }^{1} \mathrm{H} \mathrm{NMR}\left(\mathrm{CDCl}_{3}, 400 \mathrm{MHz}\right) \delta_{\mathrm{H}} 6.42(\mathrm{~d}, J=2.8 \mathrm{~Hz}, 1 \mathrm{H}, \mathrm{H}-$ 5), $6.34(\mathrm{~d}, J=2.8 \mathrm{~Hz}, 1 \mathrm{H}, \mathrm{H}-3), 6.29(\mathrm{br} \mathrm{s}, 1 \mathrm{H}, \mathrm{OH}), 4.42(\mathrm{dd}, 1 \mathrm{H}, J$ $\left.=7.7,5.7 \mathrm{~Hz}, \mathrm{H}-1^{\prime}\right), 3.86\left(\mathrm{~s}, 3 \mathrm{H}, \mathrm{CH}_{3}\right), 3.76\left(\mathrm{~s}, 3 \mathrm{H}, \mathrm{CH}_{3}\right), 3.30(\mathrm{~s}$, $\left.3 \mathrm{H}, \mathrm{CH}_{3}\right), 1.87-1.74\left(\mathrm{~m}, 1 \mathrm{H}, \mathrm{H}-2^{\prime}\right), 1.73-1.61\left(\mathrm{~m}, 1 \mathrm{H}, \mathrm{H}-2^{\prime}\right)$, $1.49-1.17\left(\mathrm{~m}, 24 \mathrm{H}, \mathrm{H}-3^{\prime}-\mathrm{H}-14^{\prime}\right), 0.87\left(\mathrm{t}, 3 \mathrm{H}, J=6.9 \mathrm{~Hz}, \mathrm{H}-15^{\prime}\right)$; ${ }^{13} \mathrm{C} \mathrm{NMR}\left(\mathrm{CDCl}_{3}, 101 \mathrm{MHz}\right) \delta_{\mathrm{C}} 153.2(\mathrm{C}, \mathrm{C}-4), 147.8$ (C, C-6), 138.1 (C, C-1), 127.2 (C, C-2), 104.5 (CH, C-3), 98.7 (CH, C-5), $81.2\left(\mathrm{CH}, \mathrm{C}-1^{\prime}\right), 57.2\left(\mathrm{CH}_{3}, \mathrm{C}-1^{\prime}-\mathrm{OCH}_{3}\right), 56.1\left(\mathrm{CH}_{3}, \mathrm{OCH}_{3}\right), 55.8$ $\left(\mathrm{CH}_{3}, \mathrm{OCH}_{3}\right), 36.5\left(\mathrm{CH}_{2}, \mathrm{C}-2^{\prime}\right),\left[32.1\left(\mathrm{CH}_{2}\right), 29.8\left(\mathrm{CH}_{2}\right), 29.8\right.$ $\left(\mathrm{CH}_{2}\right), 29.8\left(\mathrm{CH}_{2}\right), 29.7\left(\mathrm{CH}_{2}\right), 29.7\left(\mathrm{CH}_{2}\right), 29.5\left(\mathrm{CH}_{2}\right), 25.9$ $\left.\left(\mathrm{CH}_{2}\right), 22.8\left(\mathrm{CH}_{2}\right), \mathrm{C}-3^{\prime}-\mathrm{C}-14^{\prime}\right], 14.2\left(\mathrm{CH}_{3}, \mathrm{C}-15^{\prime}\right)$; HRESIMS $\mathrm{m} /$ $z 393.3036[\mathrm{M}-\mathrm{H}]^{-}$(calcd for $\left.\mathrm{C}_{24} \mathrm{H}_{41} \mathrm{O}_{4}^{-}, 393.3010\right)$.

2-Chloro-6-hydroxy-3,5-dimethoxybenzaldehyde (6). In a roundbottom flask compound $3(100.1 \mathrm{mg}, 0.5494 \mathrm{mmol})$ was dissolved in anhydrous THF $(10 \mathrm{~mL})$ followed by addition of NCS $(73.0 \mathrm{mg}$, $0.550 \mathrm{mmol}$ ). To the resulting solution was added concentrated $\mathrm{HCl}$ $(1 \mathrm{~mL})$, and the reaction developed a strong yellow color. The reaction was left stirring for $15 \mathrm{~min}$, and after that cold deionized $\mathrm{H}_{2} \mathrm{O}$ $(50 \mathrm{~mL})$ was added to the reaction and the flask was placed in an icewater bath to induce precipitation. The precipitate was collected by filtration and washed with cold $\mathrm{H}_{2} \mathrm{O}$. After drying, compound $\mathbf{6}$ was obtained $(107.1 \mathrm{mg}, 90 \%)$ as a yellow solid, with no need of further purifications. $\mathrm{Mp}=100-105{ }^{\circ} \mathrm{C} ;{ }^{1} \mathrm{H}$ NMR $\left(\mathrm{CDCl}_{3}, 400 \mathrm{MHz}\right) \delta_{\mathrm{H}}$ 11.75 (s, 1H, OH), 10.44 (s, CHO), 6.84 (s, H-4), 3.92 (s, 3H, $\left.\mathrm{OCH}_{3}\right), 3.89\left(\mathrm{~s}, 3 \mathrm{H}, \mathrm{OCH}_{3}\right) ;{ }^{13} \mathrm{C} \mathrm{NMR}\left(\mathrm{CDCl}_{3}, 101 \mathrm{MHz}\right) \delta_{\mathrm{C}} 196.2$ (C, CHO), 148.6 (C, C-3), 147.9 (C, C-6), 147.8 (C, C-5), 116.6 $(\mathrm{CH}, \mathrm{C}-1), 115.8(\mathrm{CH}, \mathrm{C}-2), 106.9(\mathrm{CH}, \mathrm{C}-4), 58.0\left(\mathrm{CH}_{3}, \mathrm{OCH}_{3}\right)$, $56.8\left(\mathrm{CH}_{3}, \mathrm{OCH}_{3}\right)$; HRESIMS $m / z 215.0120[\mathrm{M}-\mathrm{H}]^{-}$(calcd for $\left.\mathrm{C}_{9} \mathrm{H}_{8} \mathrm{ClO}_{4}^{-}, 215.0117\right)$.

3-Chloro-4,6-dimethoxy-2-(1-hydroxypentadecyl)phenol (7). Following the same protocol described for the preparation of 4 , compound 6 (95.0 mg, $0.439 \mathrm{mmol})$ was reacted with tetradecylmagnesium chloride $1.0 \mathrm{M}$ in THF $(0.9 \mathrm{~mL}, 0.9 \mathrm{mmol})$, and the resulting solution was left under stirring for $2 \mathrm{~h}$. After the typical workup the desired compound was then induced to precipitate from the crude oil using $n$-hexane. The solid was filtered and washed with fresh portions of $n$-hexane, affording $7(143.8 \mathrm{mg}, 79 \%)$ as a yelloworange solid. $\mathrm{Mp}=73-75{ }^{\circ} \mathrm{C} ;{ }^{1} \mathrm{H} \mathrm{NMR}\left(\mathrm{CDCl}_{3}, 400 \mathrm{MHz}\right) \delta_{\mathrm{H}} 7.49$ (br s, OH), $6.46(\mathrm{~s}, 1 \mathrm{H}, \mathrm{H}-5), 5.30-5.22\left(\mathrm{~m}, 1 \mathrm{H}, \mathrm{H}-1^{\prime}\right), 3.88(\mathrm{~s}, 3 \mathrm{H}$, $\left.\mathrm{OCH}_{3}\right), 3.83\left(\mathrm{~s}, 3 \mathrm{H}, \mathrm{OCH}_{3}\right), 3.47$ (br s, $\left.1 \mathrm{H}, \mathrm{H}-1\right), 1.96-1.82(\mathrm{~m}$, $\left.1 \mathrm{H}, \mathrm{H}-2^{\prime}\right), 1.81-1.70\left(\mathrm{~m}, 1 \mathrm{H}, \mathrm{H}-2^{\prime}\right), 1.58-1.47\left(\mathrm{~m}, 1 \mathrm{H}, \mathrm{H}-3^{\prime}\right)$, $1.40-1.20\left(\mathrm{~m}, 21 \mathrm{H}, \mathrm{H}-3^{\prime}-\mathrm{H}-14^{\prime}\right), 0.87\left(\mathrm{t}, 3 \mathrm{H}, J=6.8 \mathrm{~Hz}, \mathrm{H}-15^{\prime}\right)$; ${ }^{13} \mathrm{C}$ NMR $\left(\mathrm{CDCl}_{3}, 101 \mathrm{MHz}\right) \delta_{\mathrm{C}} 148.5$ (C, C-4), 146.4 (C, C-6), 139.4 (C, C-1), 127.5 (C, C-2), 112.3 (C, C-3), 97.5 (CH, C-5), 73.0 $\left(\mathrm{CH}, \mathrm{C}-1^{\prime}\right), 57.3\left(\mathrm{CH}_{3}, \mathrm{OCH}_{3}\right), 56.5\left(\mathrm{CH}_{3}, \mathrm{OCH}_{3}\right), 36.1\left(\mathrm{CH}_{2}, \mathrm{C}-\right.$ $\left.2^{\prime}\right), 32.1\left(\mathrm{CH}_{2}, \mathrm{C}-3^{\prime}\right),\left[29.8\left(\mathrm{CH}_{2}\right), 29.8\left(\mathrm{CH}_{2}\right), 29.8\left(\mathrm{CH}_{2}\right), 29.7\right.$ $\left.\left(\mathrm{CH}_{2}\right), 29.5\left(\mathrm{CH}_{2}\right), 29.5\left(\mathrm{CH}_{2}\right), 25.8\left(\mathrm{CH}_{2}\right), \mathrm{C}-4^{\prime}-\mathrm{C}-13^{\prime}\right], 22.8$ $\left(\mathrm{CH}_{2}, \mathrm{C}-14^{\prime}\right), 14.2\left(\mathrm{CH}_{3}, \mathrm{C}-15^{\prime}\right)$; HRESIMS $m / z 413.2488[\mathrm{M}-$ $\mathrm{H}]^{-}$(calcd for $\left.\mathrm{C}_{23} \mathrm{H}_{38} \mathrm{ClO}_{4}^{-}, 413.2464\right)$.

(Z)-3-Chloro-4,6-dimethoxy-2-(pentadec-1-en-1-yl)phenol (8). In a round-bottom flask previously flushed with argon, the Wittig reagent myristyltriphenylphosphonium bromide $(227.9 \mathrm{mg}, 0.4224 \mathrm{mmol}$ ) was dissolved in anhydrous THF $(20 \mathrm{~mL})$ and treated with ${ }^{n} \mathrm{BuLi}$ $(0.26 \mathrm{~mL}, 0.42 \mathrm{mmol})$ for $15 \mathrm{~min}$. After that, compound $6(76.2 \mathrm{mg}$, $0.352 \mathrm{mmol}$ ) was added, and the reaction was left stirring overnight. The resulting solution was concentrated in vacuo, then dissolved in $\mathrm{CH}_{2} \mathrm{Cl}_{2}(20 \mathrm{~mL})$, and transferred into a separatory funnel followed by the addition of $\mathrm{H}_{2} \mathrm{O}$. The phases were separated, the organic phase was washed with $\mathrm{H}_{2} \mathrm{O}(3 \times 20 \mathrm{~mL})$, dried over anhydrous $\mathrm{Na}_{2} \mathrm{SO}_{4}$, and filtered, and the filtrate was concentrated in vacuo. The resulting residue was chromatographed using hexane/EtOAc $(3: 1)$ to afford alkene $8(112.3 \mathrm{mg}, 88 \%)$ as a white solid. $\mathrm{Mp}=58-60{ }^{\circ} \mathrm{C} ;{ }^{1} \mathrm{H}$ NMR $\left(\mathrm{CDCl}_{3}, 400 \mathrm{MHz}\right) \delta_{\mathrm{H}} 6.65-6.34\left(\mathrm{~m}, 3 \mathrm{H}, \mathrm{H}-5+\mathrm{H}-1^{\prime}+\mathrm{H}-2^{\prime}\right), 5.65$ $(\mathrm{s}, 1 \mathrm{H}, \mathrm{OH}), 3.90\left(\mathrm{~s}, 3 \mathrm{H}, \mathrm{OCH}_{3}\right), 3.85\left(\mathrm{~s}, 3 \mathrm{H}, \mathrm{OCH}_{3}\right), 2.28(\mathrm{dd}, 2 \mathrm{H}$, $\left.J=13.1,7.1 \mathrm{~Hz}, \mathrm{H}-3^{\prime}\right), 1.59-1.15\left(\mathrm{~m}, 22 \mathrm{H}, \mathrm{H}-4^{\prime}-\mathrm{H}-14^{\prime}\right), 0.88(\mathrm{t}$, $\left.3 \mathrm{H}, J=6.8 \mathrm{~Hz}, \mathrm{H}-15^{\prime}\right) ;{ }^{13} \mathrm{C} \mathrm{NMR}\left(\mathrm{CDCl}_{3}, 101 \mathrm{MHz}\right) \delta_{\mathrm{C}} 148.7(\mathrm{C}$, C-4), 145.3 (C, C-6), 139.3 (C, C-2'), 138.7 (C, C-1), 123.5 (C, C2), $122.4\left(\mathrm{CH}, \mathrm{C}-1^{\prime}\right), 114.5(\mathrm{CH}, \mathrm{C}-3), 96.6(\mathrm{CH}, \mathrm{C}-5), 57.6\left(\mathrm{CH}_{3}\right.$ $\left.\mathrm{OCH}_{3}\right), 56.6\left(\mathrm{CH}_{3}, \mathrm{OCH}_{3}\right), 34.3\left(\mathrm{CH}_{2}, \mathrm{C}-3^{\prime}\right)$, [32.1 $\left(\mathrm{CH}_{2}, \mathrm{C}-2^{\prime}\right)$, $29.8\left(\mathrm{CH}_{2}\right), 29.8\left(\mathrm{CH}_{2}\right), 29.8\left(\mathrm{CH}_{2}\right), 29.8\left(\mathrm{CH}_{2}\right), 29.8\left(\mathrm{CH}_{2}\right), 29.5$ $\left.\left(\mathrm{CH}_{2}\right), 29.4\left(\mathrm{CH}_{2}\right), \mathrm{C}-4^{\prime}-\mathrm{C}-13^{\prime}\right], 22.8\left(\mathrm{CH}_{2}, \mathrm{C}-14^{\prime}\right), 14.3\left(\mathrm{CH}_{3}, \mathrm{C}-\right.$ $15^{\prime}$ ); HRESIMS $m / z$ 395.2374 $[\mathrm{M}-\mathrm{H}]^{-}$(calcd for $\mathrm{C}_{23} \mathrm{H}_{36} \mathrm{ClO}_{3}{ }^{-}$, 395.2359).

3-Chloro-4,6-dimethoxy-2-(pentadecyl)phenol (Hierridin C, 2). In a round-bottom flask compound $8(82.0 \mathrm{mg}, 0.207 \mathrm{mmol})$ was dissolved in EtOAc $(20 \mathrm{~mL})$ followed by addition of catalytic amounts of $\mathrm{Pd} / \mathrm{C} 10 \%(\mathrm{w} / \mathrm{w})$, and the resulting suspension was cooled to $0{ }^{\circ} \mathrm{C}$ using an ice bath. The system was purged with $\mathrm{H}_{2}$ via balloon, and the reaction was left stirring for $1 \mathrm{~h}$ until consumption of the starting material. After that, the suspension was filtered over a Celite pad and washed with EtOAc. The filtrate was concentrated in vacuo, and the resulting residue was chromatographed using EtOAc/ hexanes (1:3) to afford hierridin $\mathrm{C}(82.3 \mathrm{mg}$, quantitative) as a white solid. $\mathrm{Mp}=42-44{ }^{\circ} \mathrm{C} ;{ }^{1} \mathrm{H}$ NMR (DMSO- $\left.d_{6}, 600 \mathrm{MHz}\right) \delta_{\mathrm{H}} 8.28(\mathrm{~s}$, $1 \mathrm{H}, \mathrm{OH}), 6.66$ (s, $1 \mathrm{H}, \mathrm{H}-5), 3.81$ (s, 3H, H-8), 3.77 (s, 3H, H-7), $2.72-2.60\left(\mathrm{~m}, 2 \mathrm{H}, \mathrm{H1}^{\prime}\right), 1.47-1.38\left(\mathrm{~m}, 2 \mathrm{H}, \mathrm{H}-2^{\prime}\right), 1.34-1.16(\mathrm{~m}$, $\left.24 \mathrm{H}, \mathrm{H}-3^{\prime}-\mathrm{H}-14^{\prime}\right), 0.85\left(\mathrm{t}, 3 \mathrm{H}, J=6.8 \mathrm{~Hz}, \mathrm{H}-15^{\prime}\right) ;{ }^{13} \mathrm{C}$ NMR (DMSO- $\left.d_{6}, 150 \mathrm{MHz}\right) \delta_{\mathrm{C}} 147.6$ (C, C-4), 146.3 (C, C-6), 138.4 (C, C-1), 128.0 (C, C-2), 112.8 (C, C-3), 96.6 (CH, C-5), $56.6\left(\mathrm{CH}_{3}\right.$, $\left.\mathrm{OCH}_{3}\right), 56.1\left(\mathrm{CH}_{3}, \mathrm{OCH}_{3}\right)$, [31.2 $\left(\mathrm{CH}_{2}\right), 29.0\left(\mathrm{CH}_{2}\right), 29.0\left(\mathrm{CH}_{2}\right)$, $29.0\left(\mathrm{CH}_{2}\right), 28.9\left(\mathrm{CH}_{2}\right), 28.8\left(\mathrm{CH}_{2}\right), 28.6\left(\mathrm{CH}_{2}\right), 28.2\left(\mathrm{CH}_{2}\right), \mathrm{C}-$ $\left.2^{\prime}-\mathrm{C}-13^{\prime}\right] 27.0\left(\mathrm{CH}_{2}, \mathrm{C}-1^{\prime}\right), 22.0\left(\mathrm{CH}_{2}, \mathrm{C}-14^{\prime}\right), 13.9\left(\mathrm{CH}_{3}, \mathrm{C}-15^{\prime}\right)$.

1,3-Dimethoxy-5-pentadecylbenzene (11). A solution of 5pentadecylresorcinol $(9,20.1 \mathrm{mg}, 0.0627 \mathrm{mmol})$ in acetone $(4 \mathrm{~mL})$ was prepared in a round-bottom flask followed by the addition of $\mathrm{K}_{2} \mathrm{CO}_{3}(19.0 \mathrm{mg}, 0.138 \mathrm{mmol})$ and dimethyl sulfate $(13.0 \mu \mathrm{L}, 0.138$ $\mathrm{mmol}$ ). The reaction was heated to $50{ }^{\circ} \mathrm{C}$ and left under stirring for $24 \mathrm{~h}$. The solvent was then removed under reduced pressure, and the crude mixture was chromatographed using hexane/EtOAc $(3: 1)$ as eluent, affording compound $11(16.5 \mathrm{mg}, 75 \%)$ as a pale yellow solid. $\mathrm{Mp}=36-38{ }^{\circ} \mathrm{C} ;{ }^{1} \mathrm{H}$ NMR $\left(\mathrm{CDCl}_{3}, 400 \mathrm{MHz}\right) \delta_{\mathrm{H}} 6.35(\mathrm{~d}, 2 \mathrm{H}, J=$ 
$2.3 \mathrm{~Hz}, \mathrm{H} 4+\mathrm{H} 6), 6.30(\mathrm{t}, 1 \mathrm{H}, J=2.3 \mathrm{~Hz}, \mathrm{H} 2), 3.78(\mathrm{~s}, 6 \mathrm{H}, 2 \times$ $\left.\mathrm{OCH}_{3}\right), 2.60-2.48\left(\mathrm{~m}, 2 \mathrm{H}, \mathrm{H} 1^{\prime}\right), 1.66-1.55\left(\mathrm{~m}, 2 \mathrm{H}, \mathrm{H} 2^{\prime}\right), 1.36-$ $1.22\left(\mathrm{~m}, \mathrm{H} 3^{\prime}-\mathrm{H} 14^{\prime}\right), 0.89\left(\mathrm{t}, 3 \mathrm{H}, J=6.9 \mathrm{~Hz}, \mathrm{H} 15^{\prime}\right) ;{ }^{13} \mathrm{C}$ NMR $(\mathrm{CDCl} 3,101 \mathrm{MHz}) \delta_{\mathrm{C}} 160.8(2 \mathrm{C}, \mathrm{C} 1+\mathrm{C} 3), 145.6(\mathrm{C}, \mathrm{C} 5), 106.6$ (2CH, C4 + C6), $97.7(\mathrm{CH}, \mathrm{C} 2), 55.4\left(2 \mathrm{CH} 3,2 \times \mathrm{OCH}_{3}\right), 36.5$ $\left(\mathrm{CH}_{2}, \mathrm{Cl}^{\prime}\right)$, $32.1\left(\mathrm{CH}_{2}, \mathrm{C2}{ }^{\prime}\right)$, [31.4 $\left(\mathrm{CH}_{2}\right), 29.9\left(\mathrm{CH}_{2}\right), 29.9\left(\mathrm{CH}_{2}\right)$, $29.8\left(\mathrm{CH}_{2}\right), 29.8\left(\mathrm{CH}_{2}\right), 29.8\left(\mathrm{CH}_{2}\right), 29.7\left(\mathrm{CH}_{2}\right), 29.5\left(\mathrm{CH}_{2}\right), \mathrm{C}^{\prime}-$ C13'], $22.8\left(\mathrm{CH}_{2}, \mathrm{C} 14^{\prime}\right), 14.3\left(\mathrm{CH}_{3}, \mathrm{C} 15^{\prime}\right) ;$ HRESIMS $\mathrm{m} / \mathrm{z}$ $349.3100[\mathrm{M}+\mathrm{H}]^{+}$(calcd for $\left.\mathrm{C}_{23} \mathrm{H}_{41} \mathrm{O}_{2}{ }^{+}, 349.3101\right)$.

Biological Assays. Human Cell Line Cytotoxicity Assays. The following cell lines were exposed to metabolite 2: hepatocellular carcinoma HepG2, colon adenocarcinoma HT-29, neuroblastoma SH-SY5Y, breast carcinoma T47D, and normal prostate cell line PNT2 (Sigma-Aldrich), breast adenocarcinoma and RKO colon carcinoma (ATCC), and MG-63 osteosarcoma (ATCC). Cells were cultured as previously described. ${ }^{6}$ Cells were seeded in 96-well culture plates at a concentration of $10^{4}$ cells cm $\mathrm{cm}^{-2}$. After $24 \mathrm{~h}$ of adhesion, cells were exposed for 24 or $48 \mathrm{~h}$ to $99 \mu \mathrm{L}$ of fresh medium supplemented with $1 \mu \mathrm{L}$ of 2 in DMSO to final concentrations of 3 and $30 \mu \mathrm{g} \mathrm{mL}^{-1}$. After incubation, cells were exposed to $10 \mu \mathrm{L}$ of 0.5 $\mathrm{mg} \mathrm{mL}{ }^{-1} \mathrm{MTT}^{32}$ Following exposure, purple-colored formazan salts were dissolved in $100 \mu \mathrm{L}$ of DMSO and the absorbance was measured at $550 \mathrm{~nm}$ in a microplate reader (Synergy HT, Biotek). All tests were run in triplicate.

Antiplasmodial Assays. Laboratory-adapted P. falciparum 3D7 and Dd2 strains were continuously cultured as previously described, ${ }^{33}$ with minor modifications. Briefly, parasites were cultivated on human erythrocytes suspended in RPMI 1640 medium supplemented with 25 mM HEPES, $6.8 \mathrm{mM}$ hypoxanthine, and 10\% AlbuMAX II (Life Technologies), at $\mathrm{pH}$ 7.2. Cultures were maintained at $37^{\circ} \mathrm{C}$ under an atmosphere of $5 \% \mathrm{O}_{2}$ and $3-5 \% \mathrm{CO}_{2}$ and $\mathrm{N}_{2}$ and synchronized by sorbitol treatment prior to the assays. ${ }^{34}$ Staging and parasitemia were determined by light microscopy of Giemsa-stained thin blood smears. The antimalarial activities of $\mathbf{1}$ and $\mathbf{2}$ were determined using the SYBR Green I (Life Technologies) assay as previously described ${ }^{35}$ with modifications. Briefly, early ring stage parasites were tested in triplicate in a 96-well plate and incubated with drugs for $48 \mathrm{~h}$ (37 ${ }^{\circ} \mathrm{C}, 5 \% \mathrm{CO}_{2}$ ), and parasite growth was assessed with SYBR Green I. Each compound was tested in a concentration ranging from 10 to $0.0097 \mu \mathrm{M}$ (0.2\% DMSO). Fluorescence intensity was measured with a multimode microplate reader (Triad, Dynex) with excitation and emission wavelengths of 485 and $535 \mathrm{~nm}$, respectively. The fluorescence data of parasites treated with 1 or 2 were expressed as percent survival relative to parasites not exposed to the compounds and analyzed by nonlinear regression using GraphPad Prism 5 (GraphPad Software). Data were averaged from two independent experiments for 3D7 and three for Dd2, each done in triplicate (six and nine determinations in total, respectively). $\mathrm{IC}_{50}$ values and standard deviations were determined using the same software package.

Genome Sequencing and Mining. Genomic DNA was isolated from a fresh pellet of a Cyanobium sp. LEGE 06113 culture, using a CTAB- $\mathrm{CHCl}_{3}$ /isoamyl alcohol-based protocol. ${ }^{36}$ The gDNA was fragmented using the AB Library Builder System (Applied Biosystems) and subsequently submitted for sequencing on the Ion Torrent PGM (ThermoFisher Scientific) platform. After sequencing, the reads were evaluated for quality using FastQC $25^{37}$ followed by assembling with SPAdes version 3.7.0.26. ${ }^{38}$ Using the Geneious 8.0 software package (Biomatters), the generated contigs were used to set up a local database. The cyanobacterial type III PKS CylI (GenBank: AFV96143) amino acid sequence was used to perform a tblastn search against the local database of Cyanobium sp. LEGE 06113 genome data. A single hit was found (e-value $2.4 \mathrm{e}-29$ ), within a $387 \mathrm{~kb}$ contig. The genomic context of these genes was annotated manually, by using the products of the predicted ORFs as queries in BlastP searches against the NCBI protein database (Table S1). Because Cyanobium sp. LEGE 06113 is not axenic, and in spite of the close homology of the hid cluster genes to cyanobacterial nucleotide data in GenBank, additional Blastn searches were made in different regions of the contig, which invariably revealed a top Blast hit sequence of cyanobacterial origin. Annotated nucleotide data have been deposited in GenBank under accession numbers MH824152 (hid cluster) and MK268689-MK268691 (genes encoding RebH/KtzR homologues).

Heterologous Expression of hidA in E. coli and Metabolite Profiling. Cloning of hidA. Forward (NdeI-hidA-v2, 5' GAG ATC TCA TAT GGG TGG GCG CTC GGC $3^{\prime}$ ) and reverse (HindIIIhidA-NHis, 5' GAT CCA AGC TTT CAT CCA GCC GGA GCC $\left.3^{\prime}\right)$ primers containing recognition sequences for NdeI and HindIII, respectively, were used to amplify the hidA gene from the gDNA of Cyanobium sp. LEGE 06113. The hid gene cluster has a high GC content, and successful amplification by PCR required an optimized two-step protocol that used the Phusion High Fidelity DNA Polymerase (New England Biolabs) with GC buffer and DMSO. The PCR reactions were prepared in a volume of $20 \mu \mathrm{L}$ containing $1 \times$ GC buffer, $200 \mu \mathrm{M}$ dNTPs, $0.75 \mu \mathrm{M}$ of each primer, $3 \%$ DMSO, $0.4 \mathrm{U}$ Phusion polymerase, and $1 \mu \mathrm{L}$ of template gDNA. The thermal cycling protocol consisted of an initial denaturation step at $98{ }^{\circ} \mathrm{C}$ for $45 \mathrm{~s}$, followed by 35 cycles of a $10 \mathrm{~s}$ denaturation step $\left(98^{\circ} \mathrm{C}\right)$ and a $30 \mathrm{~s}$ annealing/extension step at $72{ }^{\circ} \mathrm{C}$, before a final extension at 72 ${ }^{\circ} \mathrm{C}$ for $7 \mathrm{~min}$. The resulting PCR mixture was loaded onto a $1 \%$ agarose gel stained with Sybr Safe and visualized under a blue light transilluminator, before excision of a slice containing the single band ( $\sim 800 \mathrm{bp})$. The DNA was purified from the agarose using the Illustra GFX PCR DNA and gel band purification kit (GE Healthcare) and ligated to a pET-28a vector (Novagen), using T4 DNA ligase (Takara) after double digestions with NdeI and HindIII (NZYTech). The resulting pET-28a-hidA construct encoded a NHis $_{6}$-tagged version of HidA and was cloned into E. coli BL21 DE3 chemically competent cells (NZYTech).

Heterologous Overexpression of HidA. The pET-28a-hidA construct led to overexpression of a $\sim 35 \mathrm{kDa}$ protein in $E$. coli BL21 DE3 cells in LB medium (expected MW for N-His ${ }_{6}$-HidA is 31 $\mathrm{kDa}$ ) that was most evident at $37^{\circ} \mathrm{C}$ without IPTG addition (Figure S12); therefore such conditions were used in the in vivo assays. These were carried out using E. coli DE3 cells carrying either the pET-28ahidA or the empty pET-28a plasmid that were cultured at $37^{\circ} \mathrm{C}$ in a shaker $(200 \mathrm{rpm})$ until reaching an $\mathrm{OD}_{600}$ of 0.3 . At that point, $30 \mu \mathrm{L}$ of a $10 \mathrm{mM}$ solution of 5-pentadecylresorcinol (9) in DMSO (or 30 $\mu \mathrm{L}$ of DMSO, as a control) was added to each culture. Following overnight growth, cell pellets were extracted with EtOAc and $\mathrm{MeOH}$ (pooled and repeated three times for each solvent). After solvent removal in a rotary evaporator, the resulting extracts were dried and kept at $-20{ }^{\circ} \mathrm{C}$ until being used for HPLC separation or LCHRESIMS analysis.

HPLC Analysis of E. coli Extracts, Peak Collection, and LC HRESIMS Analysis. The E. coli extracts resulting from the feeding experiments with substrate 9 were resuspended in $\mathrm{MeOH}(1 \mathrm{mg}$ $\mathrm{mL}^{-1}$ ) and analyzed by HPLC-PDA. Separation was carried out in a Synergi $4 \mathrm{u}$ Fusion-RP column $(250 \times 10 \mathrm{~mm}$, Phenomenex $)$ using a linear gradient from $20 \% \mathrm{MeCN}$ (aq) to $100 \% \mathrm{MeCN}$ over $20 \mathrm{~min}$, held for 25 additional minutes before returning to the initial conditions. The flow rate was $3 \mathrm{~mL} \mathrm{~min}{ }^{-1}$ and the injection volume was $40 \mu \mathrm{L}$. Two peaks that were only observed for the extract of $E$. coli cells carrying the pET-28a-hidA plasmid and supplemented with compound 9 were collected individually $\left(t_{\mathrm{R}}=23.8\right.$ and $\left.30.2 \mathrm{~min}\right)$ and pooled from multiple injections (scaled-up to $250 \mu \mathrm{L}$ ). After evaporation of the eluents in a rotary evaporator, the two collected peak samples were resuspended in a 1:10:4 solution of $\mathrm{CHCl}_{3}$ / $\mathrm{MeOH} / \mathrm{MeCN}$ to a concentration of $1 \mathrm{mg} \mathrm{mL}^{-1}$ and filtered through $0.2 \mu \mathrm{m}$ syringe filters. The samples, together with a $500 \mu \mathrm{M}$ standard of compound 9 prepared in $\mathrm{MeOH}$ were then used for LC-HRESIMS analysis on a system composed of a Dionex Ultimate 3000 HPLC system coupled to a qExactive Focus Orbitrap mass spectrometer, controlled by XCalibur 4.1 software (Thermo Fisher Scientific). Separation was carried out in a Luna C18 column $(3 \mu \mathrm{m}, 100 \times 3$ $\mathrm{mm}$, Phenomenex) under a flow rate of $0.4 \mathrm{~mL} \mathrm{~min}^{-1}$, with a gradient from $60 \%$ solution $\mathrm{A}\left(\mathrm{H}_{2} \mathrm{O}+0.1 \%\right.$ formic acid $) / 40 \%$ solution $\mathrm{B}$ ( $\mathrm{MeOH}+0.1 \%$ formic acid) to $100 \%$ solution $\mathrm{B}$ for $7 \mathrm{~min}$ and then held at $100 \%$ solution B for 8 additional minutes before returning to the initial conditions. The UV absorbance of the eluate was 
monitored at $280 \mathrm{~nm}$, and a full MS acquisition was carried out in positive mode (spray voltage $+2600 \mathrm{~V}$, capillary temperature $320^{\circ} \mathrm{C}$, sheath gas parameter set to 35 ). To clarify the identity of the peak collected at $t_{\mathrm{R}}=30.2$ and compare its LC-HRESIMS profile with a $500 \mu \mathrm{M}$ standard of compound 11 in $\mathrm{MeOH}$, the same instrument and analysis conditions were used, except for the elution program, which was run at $0.3 \mathrm{~mL} \mathrm{~min}{ }^{-1}$ and used a gradient from $60 \%$ solution $\mathrm{A}\left(\mathrm{H}_{2} \mathrm{O}+0.1 \%\right.$ formic acid $) / 40 \%$ solution $\mathrm{B}(\mathrm{MeCN}+0.1 \%$ formic acid) to $100 \%$ solution $\mathrm{B}$ for $7 \mathrm{~min}$ and was then held at $100 \%$ solution B for 13 additional minutes before returning to the initial conditions.

Phylogenetic Analysis of the hid Gene Cluster. The sequences of HidC homologues were retrieved from the GenBank following a BlastP search and were aligned using the MUSCLE package in the Geneious software. The resulting alignment was used for phylogenetic analysis. An approximately maximum-likelihood tree was inferred using FastTree $2^{39}$ (from within the Geneious software package). In addition, the genomic context of the corresponding hidC genes was explored and annotated (using BlastP for the predicted amino acid sequences of the surrounding open reading frames).

\section{ASSOCIATED CONTENT}

\section{Supporting Information}

The Supporting Information is available free of charge on the ACS Publications website at DOI: 10.1021/acs.jnatprod.8b01038.

NMR spectra, HRESIMS and GC-MS data, bioactivity data, detailed annotation of the hid gene cluster and its genomic context, annotation of putative halogenases, a version of the HidC-based phylogenetic tree featuring taxa/accession numbers, and additional synthesis details (PDF)

\section{AUTHOR INFORMATION}

\section{Corresponding Author}

*E-mail: pleao@ciimar.up.pt.

\section{ORCID $\odot$}

Margarida Costa: 0000-0001-9147-8621

Ivo E. Sampaio-Dias: 0000-0002-9071-6197

Valentina F. Domingues: 0000-0003-3472-849X

Pedro N. Leão: 0000-0001-5064-9164

\section{Author Contributions}

${ }^{\#}$ M. Costa, I. E. Sampaio-Dias, and R. Castelo-Branco contributed equally to this work.

\section{Notes}

The authors declare the following competing financial interest(s): The antiplasmodial activity of hierridin $\mathrm{C}$ has formed the basis for a patent application (WO2016207869) in which some co-authors are inventors.

\section{ACKNOWLEDGMENTS}

We thank CEMUP for HRESIMS and NMR analyses. This research was supported by the Structured Program of R\&D\&I INNOVMAR - Innovation and Sustainability in the Management and Exploitation of Marine Resources (reference NORTE-01-0145-FEDER-000035, Research Line NOVELMAR), funded by the Northern Regional Operational Program (NORTE2020) through the European Regional Development Fund (ERDF). This work was also funded by Fundação para a Ciência e Tecnologia (FCT), under the framework of projects UID/Multi/04423/2013, GHTM - UID/Multi/04413/2013 and PTDC/MAR-BIO/2818/2013, IFCT contract IF/01358/ 2014 to P.N.L., and Ph.D. scholarship SFRH/BD/93632/2013 to IESD. In addition, this work was also partially supported by the Associate Laboratory for Green Chemistry- LAQV, which is financed by national funds from FCT/MCTES (UID/QUI/ $50006 / 2013$ ) and cofinanced by the ERDF under the PT2020 Partnership Agreement (POCI-01-0145-FEDER-007265).

\section{REFERENCES}

(1) Tidgewell, K.; Clark, B. R.; Gerwick, W. H. In Comprehensive Natural Products II Chemistry and Biology; Mander, L., Lui, H.-W., Eds.; Elsevier: Oxford, 2010; Vol. 2, pp 141-188.

(2) Yoshizawa, S.; Matsushima, R.; Watanabe, M. F.; Harada, K.; Ichihara, A.; Carmichael, W. W.; Fujiki, H. J. Cancer Res. Clin. Oncol. 1990, 116, 609-614.

(3) Hong, J. Y.; Luesch, H. Nat. Prod. Rep. 2012, 29, 449-456.

(4) Shih, P. M.; Wu, D.; Latifi, A.; Axen, S. D.; Fewer, D. P.; Talla, E.; Calteau, A.; Cai, F.; Tandeau de Marsac, N.; Rippka, R.; Herdman, M.; Sivonen, K.; Coursin, T.; Laurent, T.; Goodwin, L.; Nolan, M.; Davenport, K. W.; Han, C. S.; Rubin, E. M.; Eisen, J. A.; Woyke, T.; Gugger, M.; Kerfeld, C. A. Proc. Natl. Acad. Sci. U. S. A. 2013, 110, $1053-1058$

(5) Scanlan, D. J.; Ostrowski, M.; Mazard, S.; Dufresne, A.; Garczarek, L.; Hess, W. R.; Post, A. F.; Hagemann, M.; Paulsen, I.; Partensky, F. Microbiol. Mol. Biol. Rev. 2009, 73, 249-299.

(6) Leão, P. N.; Costa, M.; Ramos, V.; Pereira, A. R.; Fernandes, V. C.; Domingues, V. F.; Gerwick, W. H.; Vasconcelos, V. M.; Martins, R. PLoS One 2013, 8, No. e69562.

(7) Papendorf, O.; König, G. M.; Wright, A. D. Phytochemistry 1998, 49, 2383-2386.

(8) Preisitsch, M.; Niedermeyer, T. H. J.; Heiden, S. E.; Neidhardt, I.; Kumpfmüller, J.; Wurster, M.; Harmrolfs, K.; Wiesner, C.; Enke, H.; Müller, R.; Mundt, S. J. Nat. Prod. 2016, 79, 106-115.

(9) Costa, M.; Sampaio-Dias, I. E.; Castelo-Branco, R.; Scharfenstein, H.; Rezende de Castro, R.; Silva, A.; Schneider, M. P. C.; Araújo, M. J.; Martins, R.; Domingues, V. F.; Nogueira, F.; Vasconcelos, V. M.; Leão, P. N. ChemRxiv 2018.

(10) Masi, M.; Cimmino, A.; Boari, A.; Tuzi, A.; Zonno, M. C.; Baroncelli, R.; Vurro, M.; Evidente, A. J. Agric. Food Chem. 2017, 65, $1124-1130$

(11) Kikuchi, H.; Ito, I.; Takahashi, K.; Ishigaki, H.; Iizumi, K.; Kubohara, Y.; Oshima, Y. J. Nat. Prod. 2017, 80, 2716-2722.

(12) Niu, S.; Liu, D.; Proksch, P.; Shao, Z.; Lin, W. Mar. Drugs 2015, 13, 2526-2540.

(13) Gonzalez, A. G.; Bermejo Barrera, J.; M Rodriguez Perez, E. Phytochemistry 1992, 31, 1436-1439.

(14) Ellis, J. E.; Lenger, S. R. Synth. Commun. 1998, 28, 1517-1524.

(15) Liao, Y.-R.; Kuo, P.-C.; Huang, S.-C.; Liang, J.-W.; Wu, T.-S. Tetrahedron Lett. 2012, 53, 6202-6204.

(16) Hopkins, C. Y.; Chisholm, M. J. Can. J. Res. 1946, 24b, 208210.

(17) Mahajan, T.; Kumar, L.; Dwivedi, K.; Agarwal, D. D. Ind. Eng. Chem. Res. 2012, 51, 3881-3886.

(18) Costa, M. S.; Costa, M.; Ramos, V.; Leão, P. N.; Barreiro, A.; Vasconcelos, V.; Martins, R. J. Toxicol. Environ. Health, Part A 2015, $78,432-442$.

(19) Śliwińska-Wilczewska, S.; Maculewicz, J.; Barreiro Felpeto, A.; Latała, A. Toxins 2018, 10, 48.

(20) Nakamura, H.; Hamer, H. A.; Sirasani, G.; Balskus, E. P. J. Am. Chem. Soc. 2012, 134, 18518-18521.

(21) Funa, N.; Ozawa, H.; Hirata, A.; Horinouchi, S. Proc. Natl. Acad. Sci. U. S. A. 2006, 103, 6356-6361.

(22) Nakano, C.; Funa, N.; Ohnishi, Y.; Horinouchi, S. J. Bacteriol. 2012, 194, 1544-1551.

(23) Neumann, C. S.; Walsh, C. T.; Kay, R. R. Proc. Natl. Acad. Sci. U. S. A. 2010, 107, 5798-5803.

(24) Agarwal, V.; Miles, Z. D.; Winter, J. M.; Eustáquio, A. S.; El Gamal, A. A.; Moore, B. S. Chem. Rev. 2017, 117, 5619-5674. 
(25) Leão, P. N.; Nakamura, H.; Costa, M.; Pereira, A. R.; Martins, R.; Vasconcelos, V.; Gerwick, W. H.; Balskus, E. P. Angew. Chem., Int. Ed. 2015, 54, 11063-11067.

(26) Stasiuk, M.; Kozubek, A. Cell. Mol. Life Sci. 2010, 67, 841-860. (27) Funabashi, M.; Funa, N.; Horinouchi, S. J. Biol. Chem. 2008, 283, 13983-13991.

(28) Kay, R. R.; Berks, M.; Traynor, D. Development 1989, 107, 8190.

(29) Saito, T.; Taylor, G. W.; Yang, J.-C.; Neuhaus, D.; Stetsenko, D.; Kato, A.; Kay, R. R. Biochim. Biophys. Acta, Gen. Subj. 2006, 1760, 754-761.

(30) LEGE Culture Collection Database.

(31) Kotai, J. Nor. Inst. Water Res. Blindern Oslo 1972, 11/69, 5.

(32) Alley, M. C.; Scudiero, D. A.; Monks, A.; Hursey, M. L.; Czerwinski, M. J.; Fine, D. L.; Abbott, B. J.; Mayo, J. G.; Shoemaker, R. H.; Boyd, M. R. Cancer Res. 1988, 48, 589-601.

(33) Trager, W.; Jensen, J. B. Science 1976, 193, 673-675.

(34) Lambros, C.; Vanderberg, J. P. J. Parasitol. 1979, 65, 418-420.

(35) Machado, M.; Murtinheira, F.; Lobo, E.; Nogueira, F. Ann. Clin. Med. Microbiol. 2016, 2, 1010.

(36) Singh, S. P.; Rastogi, R. P.; Häder, D.-P.; Sinha, R. P. World J. Microbiol. Biotechnol. 2011, 27, 1225-1230.

(37) Andrews, S. 2010, available online, http://www.bioinformatics. babraham.ac.uk/projects/fastqc.

(38) Bankevich, A.; Nurk, S.; Antipov, D.; Gurevich, A. A.; Dvorkin, M.; Kulikov, A. S.; Lesin, V. M.; Nikolenko, S. I.; Pham, S.; Pribelski, A. D.; Pyshkin, A. V.; Sirotkin, A. V.; Vyahhi, N.; Tesler, G.; Alekseyev, M. A.; Pevzner, P. A. J. Comput. Biol. 2012, 19, 455-477.

(39) Price, M. N.; Dehal, P. S.; Arkin, A. P. PLoS One 2010, 5, No. e9490. 